\title{
Effects of Light Intensity and Exposure Period on the Growth and Stress Responses of Two Cyanobacteria Species: Pseudanabaena galeata and Microcystis aeruginosa
}

\author{
Guligena Muhetaer 1,*, Takashi Asaeda 2,3,4, Senavirathna M. D. H. Jayasanka 1, \\ Mahendra B. Baniya ${ }^{1,5}$, Helayaye D. L. Abeynayaka ${ }^{1}$, M. Harun Rashid ${ }^{6} \mathbb{D}$ and HongYu Yan ${ }^{1}$ \\ 1 Graduate School of Science and Engineering, Saitama University, 255 Shimo-okubo, Sakura-ku, Saitama \\ 338-8570, Japan; jayasanka@mail.saitama-u.ac.jp (S.M.D.H.J.); baniyam57@gmail.com (M.B.B.); \\ hdlakmali@yahoo.com (H.D.L.A.); en.k.943@ms.saitama-u.ac.jp (H.Y.) \\ 2 Institute for studies of the Global Environment, 7-1 Sophia University, Kioicho, Chiyoda, Tokyo 102-0094, \\ Japan; asaeda@mail.saitama-u.ac.jp \\ 3 Institute Hydro Technology Institute, 4-3-1 Shiroyama Trust Tower, Tranomon, Minato, \\ Tokyo 105-0001, Japan \\ 4 Research and Development Center, Nippon Koei, 2304 Inarihara, Tsukuba, Ibaraki 300-1259, Japan \\ 5 Provincial Government, Ministry of Physical Infrastructure Development, Gandaki Province, \\ Pokhara 33700, Nepal \\ 6 Department of Agronomy, Bangladesh Agricultural University, Mymensingh 2202, Bangladesh; \\ mhrashid@bau.edu.bdmailto \\ * Correspondence: gulgina1112@gmail.com; Tel.: +81-09064936640
}

Received: 29 November 2019; Accepted: 31 January 2020; Published: 3 February 2020

\begin{abstract}
Light is an important factor that affects cyanobacterial growth and changes in light can influence their growth and physiology. However, an information gap exists regarding light-induced oxidative stress and the species-specific behavior of cyanobacteria under various light levels. This study was conducted to evaluate the comparative effects of different light intensities on the growth and stress responses of two cyanobacteria species, Pseudanabaena galeata (strain NIES 512) and Microcystis aeruginosa (strain NIES 111), after periods of two and eight days. The cyanobacterial cultures were grown under the following different light intensities: $0,10,30,50,100,300$, and $600 \mu \mathrm{mol} \mathrm{m}^{-2} \mathrm{~s}^{-1}$. The optical density $\left(\mathrm{OD}_{730}\right)$, chlorophyll a (Chl-a) content, protein content, $\mathrm{H}_{2} \mathrm{O}_{2}$ content, and the antioxidative enzyme activities of catalase (CAT) and peroxidase (POD) were measured separately in each cyanobacteria species. P. galeata was negatively affected by light intensities lower than $30 \mu \mathrm{mol}$ $\mathrm{m}^{-2} \mathrm{~s}^{-1}$ and higher than $50 \mu \mathrm{mol} \mathrm{m} \mathrm{m}^{-2} \mathrm{~s}^{-1}$. A range of 30 to $50 \mu \mathrm{mol} \mathrm{m} \mathrm{m}^{-2} \mathrm{~s}^{-1}$ light was favorable for the growth of $P$. galeata, whereas $M$. aeruginosa had a higher tolerance for extreme light conditions. The favorable range for $M$. aeruginosa was 10 to $100 \mu \mathrm{mol} \mathrm{m}^{-2} \mathrm{~s}^{-1}$.
\end{abstract}

Keywords: cyanobacterial growth; stress responses; Pseudanabaena galeata; Microcystis aeruginosa; oxidative stress; antioxidative enzymes

\section{Introduction}

Eutrophication and global warming have promoted the growth of cyanobacteria in freshwater systems worldwide, and this trend is expected to increase in the future [1]. Cyanobacterial blooms are a serious issue in fresh, brackish, and marine water, as they decrease light penetration through the water and deplete dissolved oxygen, causing mortality for aquatic life [2]. Cyanobacteria are oxygenic autotrophs, constituting the largest and most diverse community of photosynthetic prokaryotes [3]. 
They play imperative roles in carbon and nutrient cycling in aquatic systems, as well as in degrading water quality and safety, causing numerous problems with water sources and ecosystem management [4]. From an environmental perspective, cyanobacterial blooms and their effects have been reported in the scientific literature for more than a century, and their probability and severity have both escalated over time [5]. The mass development of cyanobacteria has resulted in various negative consequences including eutrophication, ecosystem imbalances, and scenic impairments [6]. Their ability to produce toxic secondary metabolites is becoming an increasingly important environmental issue, which is threatening human, animal, and plant health. Cyanobacterial blooms can, thereby, lead to ecosystem destruction $[7,8]$. Given these problems, gaps in our knowledge of cyanobacteria must be filled.

It is important to understand the environmental factors associated with cyanobacterial growth and metabolism to address real world problems. This subject has been extensively mentioned in connection to climate change $[9,10]$, and anthropogenic activities associated with land use changes are also being experienced worldwide and have been widely discussed in the literature [11,12]. Cyanobacteria have several environmental drivers, such as water temperature, water column irradiance, and stratification of the water column coupled with long residence time, the availability of nitrogen $(\mathrm{N})$ and phosphorus $(\mathrm{P})$, and the turbidity and salinity of water. Of these drivers, light intensity is a particularly important determinant of the growth of cyanobacterial blooms [13]. The growth patterns of cyanobacteria respond to different light intensities via morphological and physiological changes [14], and detailed investigation of these changes is vital for the formulation of both proactive and reactive planning for freshwater resources management.

Pseudanabaena galeata and Microcystis aeruginosa are two cyanobacteria species that are known to degrade water quality and safety in many parts of the world [15]. P. galeata is a non-bloom-forming species, however, it forms odorous 2-methylisoborneol (2-MIB) which causes operational issues with water supplies [16]. M. aeruginosa is a bloom forming species that synthesizes secondary toxic metabolites, namely microcystins, which affect water safety, and therefore human health, thereby posing serious social and ecological hazards $[17,18]$. In addition to these concerns that arise with both species, their worldwide occurrences have increased as eutrophication and global warming which together have provided suitable conditions for vigorous growth $[19,20]$.

As the frequency of cyanobacteria blooms continues to increase, various control measures are being applied to control their growth [21]. Methods such as the mixing of water in lakes or reservoirs mainly focus on exposing cyanobacteria to low levels of light. However, the photosynthetic organisms of cyanobacteria can also be stressed by high-light exposure, and the excess energy produces reactive oxygen species (ROS), which cause severe photodamage to their cellular components [22,23]. The growth rates of Microcystis and Anabaena species are high under low-light levels $\left(25 \mu \mathrm{mol} \mathrm{m}{ }^{-2} \mathrm{~s}^{-1}\right)$, however, these growth rates decrease under high-light levels $\left(200 \mu \mathrm{mol} \mathrm{m}^{-2} \mathrm{~s}^{-1}\right)[22,24]$.

Although high-light levels can negatively affect cyanobacteria species, the responses and relationships of their oxidative stress, antioxidant, pigmentation, and protein contents are currently not well understood. Therefore, in this study, we aimed to explore the responses of P. galeata and $M$. aeruginosa to low-light and high-light stressors. We measured hydrogen peroxide $\left(\mathrm{H}_{2} \mathrm{O}_{2}\right)$, antioxidant enzymes (catalase (CAT) and peroxidase (POD)), chlorophyll a (Chl-a), protein contents, and optical densities $\left(\mathrm{OD}_{730}\right)$ under different light conditions. The growth performances of these two species were calculated and validated using cyanobacteria growth models proposed by Steele [25], Platt and Jassby [26], and Peeters and Eilers [27], to determine the applicability of our findings to cyanobacteria control.

\section{Materials and Methods}

\subsection{Cyanobacterial Cultures and Incubation}

Strains of the cyanobacterial species P. galeata and M. aeruginosa were obtained from the National Institute for Environmental Studies (NIES) at Ibaraki, Japan. The samples were cultured in BG-11 
medium [28] and acclimatized for 14 days inside an incubator (MIR-254, Sanyo, Tokyo, Japan) at $20^{\circ} \mathrm{C}$; they underwent manual shaking three to five times per day. The samples were cultured under controlled light conditions, with photon flux levels of 20 to $30 \mu \mathrm{mol} \mathrm{m}^{-2} \mathrm{~s}^{-1}$ emitted from cool white fluorescent lamps ( $5000 \mathrm{~K}$ color temperature). The cycle of light conditions to dark conditions was maintained at $12 \mathrm{~h}$ light and $12 \mathrm{~h}$ dark [29], using an automatic setup time device (REVEX PT7, Saitama, Japan).

\subsection{Growth Experimental Setup}

All of the experiments were conducted inside an incubator (MIR-254, Sanyo, Tokyo, Japan) at a constant temperature of $20{ }^{\circ} \mathrm{C}$ throughout the experimental period. To characterize the growth response to different light conditions, incubated P. galeata (NIES 512) and M. aeruginosa (NIES 111) cells were separately subjected to seven different photon flux levels $\left(0,10,30,50,100,300\right.$, and $600 \mu \mathrm{mol} \mathrm{m}{ }^{-2}$ $\mathrm{s}^{-1}$ ); a constant temperature of $20^{\circ} \mathrm{C}$ was used to calculate the saturation light intensities. Light was supplied from cold white fluorescent lamp sources. The cultures were maintained in an illumination cycle of $12 \mathrm{~h} \mathrm{light}$ and $12 \mathrm{~h}$ dark (12L:12D). Zero $\mu \mathrm{mol} \mathrm{m} \mathrm{m}^{-2} \mathrm{~s}^{-1}$ light intensity means that there was no light source; these cultures were maintained in $24 \mathrm{~h}$ of darkness. The light intensities were measured using a quantum sensor (ml-020P, EKO Instruments Co., Ltd., Tokyo, Japan), and were read as voltage output (mV) by a voltage logger (LR5041, HIOKI, Nagano, Japan). The cells that were cultured under different light levels were sampled for Chl-a and enzyme analysis in two-day intervals. To ensure the homogenous exposure of cells to the light environment, the cyanobacteria cultured flasks were shaken gently five times a day. Each treatment was performed in triplicate.

\subsection{Measuring Protein}

The concentration of protein was measured using the Bradford method [30]. A crude protein extract was discolored with Coomassie (G-250). After incubation at room temperature $\left(25 \pm 2{ }^{\circ} \mathrm{C}\right)$ for $10 \mathrm{~min}$, the absorbance was measured at $595 \mathrm{~nm}$ using an ultraviolet visible (UV-Vis) spectrometer (UVmini-1240, Shimadzu, Kyoto, Japan). Protein was diluted with the same buffer and was stained with Coomassie (G-250) dye and used to prepare the standard curve; deionized water was used as the blank.

\subsection{Measuring $O D_{730}$}

To estimate the growth of cyanobacteria, the $\mathrm{OD}_{730}$ was measured by taking $1 \mathrm{~mL}$ of sample from each flask. The $\mathrm{OD}_{730}$ was measured with a UV-Vis spectrophotometer (UVmini-1240, Shimadzu, Kyoto, Japan) at an optical absorption wavelength of $730 \mathrm{~nm}$, using a previously proposed methodology [31,32].

\subsection{Measuring Chlorophyll a Content}

The concentration of Chl-a in the cyanobacteria samples was measured according to the method described by Holm and Romo [33,34]. The $1 \mathrm{~mL}$ cell suspensions of the two species were centrifuged separately at $10,000 \times g$ for $10 \mathrm{~min}$ at $4{ }^{\circ} \mathrm{C}$, and the supernatant was removed. Each cell pellet was washed once with Milli-Q water and then extracted in $1 \mathrm{~mL}$ of $80 \%$ acetone. The mixture was shaken vigorously and maintained in darkness overnight at room temperature $\left(25 \pm 2{ }^{\circ} \mathrm{C}\right)$. Then, each sample was again centrifuged at $10,000 \times g$, and the supernatant was measured with a UV-Vis spectrophotometer (UVmini-1240, Shimadzu, Kyoto, Japan) at absorption wavelengths of 660 and $645 \mathrm{~nm}$. To correct for the absorbance for pheophytin a, the samples were acidified with $0.1 \mathrm{~N} \mathrm{HCL}$, and their absorbance was measured again. The chlorophyll a content was calculated by using Equation (1) [33]:

$$
C h l-a=\left(9.76 \times A_{660}\right)-\left(0.99 \times A_{645}\right)
$$

where $\mathrm{Chl}-a$ is the content of chlorophyll a (expressed in $\mu \mathrm{g}$ per mL), and $A_{660}$ and $A_{645}$ are the absorbance values $660 \mathrm{~nm}$ and $645 \mathrm{~nm}$, respectively. 


\subsection{Measuring $\mathrm{H}_{2} \mathrm{O}_{2}$ Content}

The method specified by Jana [35] was employed to measure the $\mathrm{H}_{2} \mathrm{O}_{2}$ concentration in the cultured cyanobacteria samples. The P. galeata (NIES 512) and M. aeruginosa (NIES 111) cell pellets were obtained by centrifuging at $10,000 \times g$ for $10 \mathrm{~min}$ and removing the supernatant. The cell pellets were washed once with Milli-Q water and homogenized in $1 \mathrm{~mL}$ of $0.1 \mathrm{M} \mathrm{pH} 6.5$ phosphate buffer to extract the internal $\mathrm{H}_{2} \mathrm{O}_{2}$. The homogenate was then centrifuged at $10,000 \times \mathrm{g}$ for $10 \mathrm{~min}$ at $4{ }^{\circ} \mathrm{C}$ and the extract was used for $\mathrm{H}_{2} \mathrm{O}_{2}$ estimation. A reaction mixture of $0.1 \%$ titanium chloride in $20 \%$ $\mathrm{H}_{2} \mathrm{SO}_{4}(\mathrm{v} / \mathrm{v})$ was added to the supernatant, and after a $1 \mathrm{~min}$ incubation period, the mixture was centrifuged at room temperature $\left(25 \pm 2{ }^{\circ} \mathrm{C}\right)$ and the absorbance was measured at $410 \mathrm{~nm}$ with a UV-Vis spectrophotometer (UVmini-1240, Shimadzu, Kyoto, Japan). The $\mathrm{H}_{2} \mathrm{O}_{2}$ concentration was determined using the pre-prepared standard curve for known concentration series. An extinction coefficient of $0.28 \mathrm{mmol}^{-1} \mathrm{~cm}^{-1}$ was used to calculate the concentration of $\mathrm{H}_{2} \mathrm{O}_{2}$ in $\mu \mathrm{mol} \mathrm{mL} \mathrm{m}^{-1}$.

\subsection{Measuring CAT Activity}

The CAT activity was measured using the method proposed by Aebi [36]. The cyanobacteria cells were homogenized in a phosphate buffer ( $\mathrm{pH} 7.0$ ), supernatant liquid was, then, taken as an enzyme extract, after being centrifuged at $12,000 \times \mathrm{g}$ at $4{ }^{\circ} \mathrm{C}$ for $10 \mathrm{~min}$. The decrease in absorbance at $240 \mathrm{~nm}$ was recorded for $3 \mathrm{~min}$. The CAT activity was calculated using an extinction coefficient of $39.4 \mathrm{mM}^{-1} \mathrm{~cm}^{-1}$.

\subsection{Measuring POD Activity}

The POD activity was measured based on guaiacol oxidation, as proposed by MacAdam [37]. The reaction mixture contained $920 \mu \mathrm{L}$ of $100 \mathrm{mM}$ potassium phosphate buffer $(\mathrm{pH} 6.8), 15 \mu \mathrm{L}$ of $0.6 \%$ $\mathrm{H}_{2} \mathrm{O}_{2}$, and $65 \mu \mathrm{L}$ of enzyme extract. The increase in absorbance was measured at $420 \mathrm{~nm}$ every $10 \mathrm{~s}$ for $3 \mathrm{~min}$.

\subsection{Cell Growth Measurement and Different Model Fitting}

The cell growth of cyanobacteria was measured using $\mathrm{OD}_{730}$ measurements. $\mathrm{OD}_{730}$ was measured using a UV-Vis spectrophotometer (UVmini-1240, Shimadzu, Kyoto, Japan).

The cell growth measurements were compared with three cell growth models that have been proposed for cyanobacteria growth [25-27]. The cell growth of cyanobacteria was measured using $\mathrm{OD}_{730}$ measurements, which were applied to the growth rate in Equation (2) [38]. Then, the calculated growth rates were compared with the three model outputs obtained for the different light intensities of the present experiment.

$$
\mu=\frac{\left(\log O D_{t}-\log O D_{0}\right)}{t} \times 3.32
$$

where $\mu$ is the cell growth rate, $\mathrm{t}$ is the time in days, $O D_{t}$ is the optical density after $\mathrm{t}$ days, and $O D_{t}$ is the optical density at the beginning of the experiment zero time. Different models proposed by Steele [25], Platt and Jassby [26], and Peeters and Eilers [27] were fitted to our experimental observations [39].

The model proposed by Steele [25], named Model I, is written as:

$$
\mu_{T, I}=\mu_{\max T} \times I / I_{o p t T} \times \exp \left(I-I / I_{o p t T}\right)
$$

where $\mu_{T, I}$ is the growth rate at light intensity $I$, and $\mu_{\max T}$ and $I_{o p t T}$ are the estimated maximal growth rates and the optimal light intensity at temperature $T$, respectively.

The model proposed by Platt and Jassby [26], named Model II, is written as:

$$
\mu_{T, I}=\mu_{\max T} \times \tan \mathrm{h}\left[\alpha \times\left(I-I_{\mathcal{C}}\right) / \mu_{\max T}\right]
$$


where $\alpha$ is the growth efficacy, $I_{c}$ is the estimated light intensity without growth $\left(I_{c} \geq 0\right)$, and tanh is the hyperbolic tangential function.

The model proposed by Peeters and Eilers [27], named Model III, is written as:

$$
\mu_{T, I}=2 \times \mu_{\max T} \times(1+\beta) \times\left(I / I_{o p t T}\right) /\left[\left(I / I_{o p t T}\right)^{2}+2 \times\left(I / I_{o p t T}\right) \times \beta+1\right]
$$

where $\beta$ is the attenuation coefficient, which allows for consideration of the photoinhibition phenomenon.

\subsection{Statistical Analysis}

All the presented results are expressed as the mean $\pm S D(n=3)$. A two-way analysis of variance (ANOVA) followed by Tukey's post-hoc tests were performed to examine the statistical significance of variations among the means between the light exposure period and light intensity combinations used for P. galeata and M. aeruginosa. Statistical analyses were performed by using IBM SPSS Statistics for Windows, Version 25.0. (Armonk, NY, USA: IBM Corp).

\section{Results}

The protein concentrations of $P$. galeata and M. aeruginosa species after two- and eight-day periods of exposure to light of different intensities are presented in Figure 1a,b. After the two-day period of exposure, the protein concentrations of each exposure condition were nearly the same as the initial values, $61.6 \pm 3.0 \mu \mathrm{g} \mathrm{mL}{ }^{-1}$ for $P$. galeata $\left(F_{6,14}=1.250\right.$ and $\left.p=0.34\right)$ and $54.5 \pm 0.70 \mu \mathrm{g} \mathrm{mL}^{-1}$ for M. aeruginosa $\left(F_{6,14}=3.960\right.$ and $\left.p=0.016\right)$. However, for $P$. galeata $\left(F_{6,14}=32.795\right.$ and $\left.p<0.0001\right)$ the concentration substantially increased after eight days. It increased rapidly up to $100 \mu \mathrm{mol} \mathrm{m} \mathrm{m}^{-2} \mathrm{~s}^{-1}$, and then continued to increase at a slower rate up to $600 \mu \mathrm{mol} \mathrm{m}^{-2} \mathrm{~s}^{-1}$. For $M$. aeruginosa $\left(F_{6,14}=34.824\right.$ and $p<0.0001$ ), the protein concentration exhibited a decreasing trend with respect to increasing light intensity, which is an almost opposite trend to that of $P$. galeata. The protein concentration of M. aeruginosa decreased rapidly up to a light intensity of $100 \mu \mathrm{mol} \mathrm{m}^{-2} \mathrm{~s}^{-1}$ and, then, continued to decrease at a slower rate up to $600 \mu \mathrm{mol} \mathrm{m}{ }^{-2} \mathrm{~s}^{-1}$.

(a)

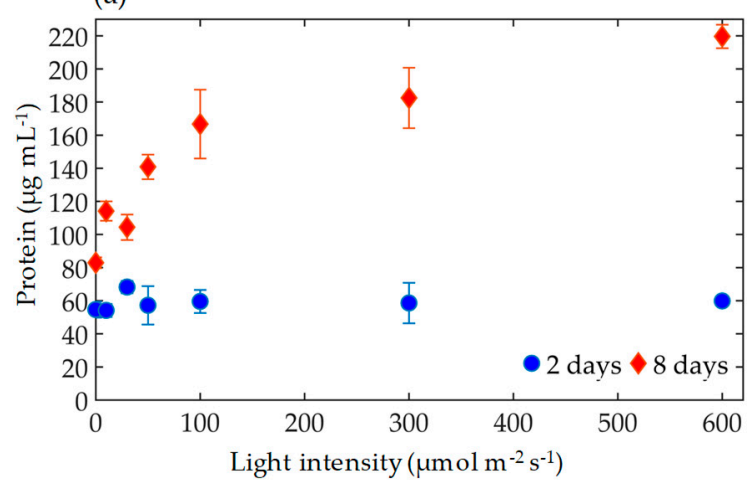

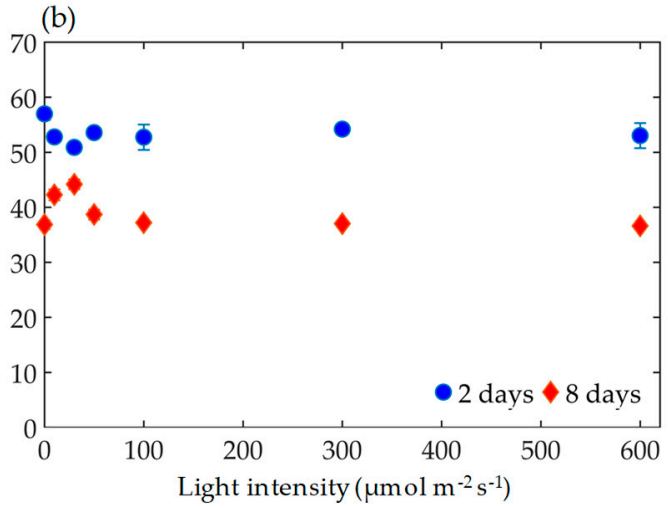

Figure 1. Changes in protein concentration with respect to light intensity after two and eight days for two species. (a) Pseudanabaena galeata; (b) Microcystis aeruginosa.

The variations in $\mathrm{OD}_{730}$ with respect to light intensity are presented in Figure 2a,b. P. galeata and $M$. aeruginosa both showed a statistically significant difference between the two- and eight-day periods of exposure ( $P$. galeata $F_{6,28}=188.811, p<0.0001$ and M. aeruginosa $\left.F_{6,28}=145.041, p<0.0001\right)$. After two days, relatively constant $\mathrm{OD}_{730}$ values were observed under all of the light intensities, for both $P$. galeata and M. aeruginosa. The eight-day $\mathrm{OD}_{730}$ value of $P$. galeata increased under 30 and 50 $\mu \mathrm{mol} \mathrm{m} \mathrm{m}^{-2} \mathrm{~s}^{-1}$ light intensities and, then, decreased under higher light intensities over the two-day 
period. However, the $\mathrm{OD}_{730}$ values of $M$. aeruginosa after eight days were approximately double the $\mathrm{OD}_{730}$ values of $P$. galeata.

(a)

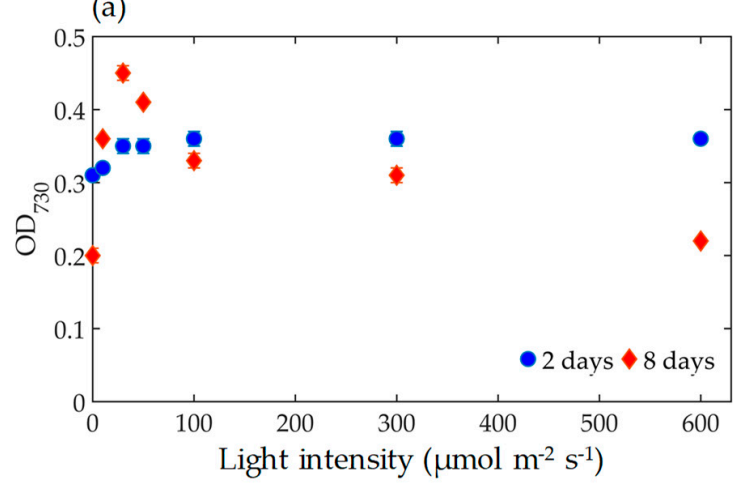

(b)

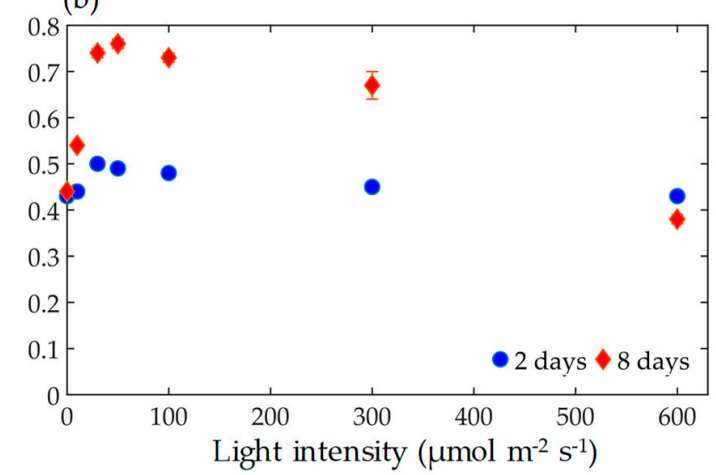

Figure 2. Changes in $\mathrm{OD}_{730}$ with respect to light intensity after two and eight days. (a) P. galeata; (b) M. aeruginosa.

The Chl-a concentrations of $P$. galeata and $M$. aeruginosa under different light intensities are presented in Figure 3a,b. The Chl-a concentrations of $P$. galeata and M. aeruginosa showed a statistically higher significant difference after eight than after two days (P. galeata $F_{6,28}=21.876, p<0.0001$ and $M$. aeruginosa $F_{6,28}=9.036, p=0.0001$ ). After the two-day exposure, the Chl-a concentrations of both species showed a slightly decreasing trend after $50 \mu \mathrm{mol} \mathrm{m}^{-2} \mathrm{~s}^{-1}$. After eight days, the Chl-a concentration increased under 30 and $50 \mu \mathrm{mol} \mathrm{m}^{-2} \mathrm{~s}^{-1}$ for $P$. galeata, however, it decreased more under the high-light intensity than that after the two-day exposure. After eight days, the Chl-a content of M. aeruginosa also followed the same trend as P. galeata, but with different values. Chl-a gradually increased up to $50 \mu \mathrm{mol} \mathrm{m}{ }^{-2} \mathrm{~s}^{-1}$ light intensity, and then started to degrade under higher light intensities.
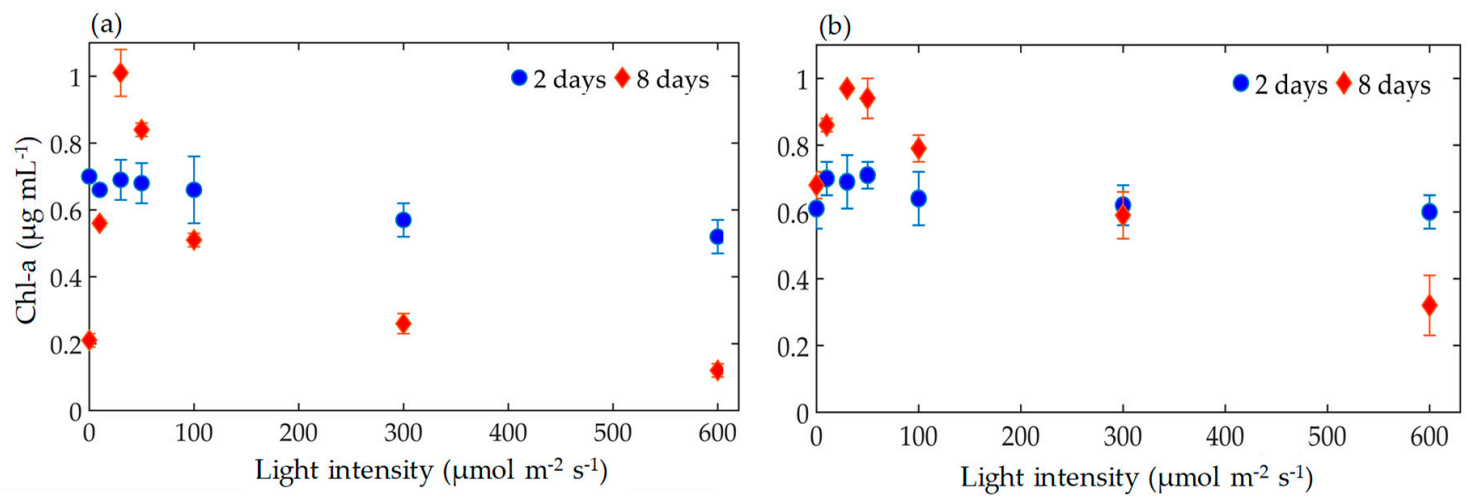

Figure 3. Changes in chlorophyll a (Chl-a) content with respect to culture light intensity. (a) P. galeata; (b) M. aeruginosa under different light intensities ( 0 to $600 \mu \mathrm{mol}$ photons $\left.\mathrm{m}^{-2} \mathrm{~s}^{-1}\right)$ after two and eight days.

The ratio of $\mathrm{H}_{2} \mathrm{O}_{2}$ per protein $\left(\mathrm{H}_{2} \mathrm{O}_{2}\right.$ /protein) over different light intensities is shown in Figure $4 a, b$. After two days, $P$. galeata's $\mathrm{H}_{2} \mathrm{O}_{2}$ /protein decreased under 30 and $50 \mu \mathrm{mol} \mathrm{m}^{-2} \mathrm{~s}^{-1}$, increased gradually up to $300 \mu \mathrm{mol} \mathrm{m} \mathrm{m}^{-2} \mathrm{~s}^{-1}$, and then remained level under $600 \mu \mathrm{mol} \mathrm{m}^{-2} \mathrm{~s}^{-1}$. After eight days, the $\mathrm{H}_{2} \mathrm{O}_{2}$ /protein was steady up to $100 \mu \mathrm{mol} \mathrm{m}^{-2} \mathrm{~s}^{-1}$ and, then, followed a decreasing trend under 300 and $600 \mu \mathrm{mol} \mathrm{m} \mathrm{m}^{-2} \mathrm{~s}^{-1}$. The $\mathrm{H}_{2} \mathrm{O}_{2} /$ protein of $M$. aeruginosa showed an increasing trend up to $100 \mu \mathrm{mol} \mathrm{m} \mathrm{m}^{-2} \mathrm{~s}^{-1}$ under both two and eight days of exposure. Then, under 300 and $600 \mu \mathrm{mol} \mathrm{m}{ }^{-2}$ $\mathrm{s}^{-1}$, we observed a slightly increasing trend for the two-day exposure and a decreasing trend for the eight-day exposure. Both $P$. galeata and $M$. aeruginosa showed a statistically significant difference in $\mathrm{H}_{2} \mathrm{O}_{2} /$ protein after eight days as compared with after two days ( $P$. galeata $F_{6,28}=9.036, p<0.0001$ and M. aeruginosa: $\left.F_{6,28}=10.864, p<0.0001\right)$. 

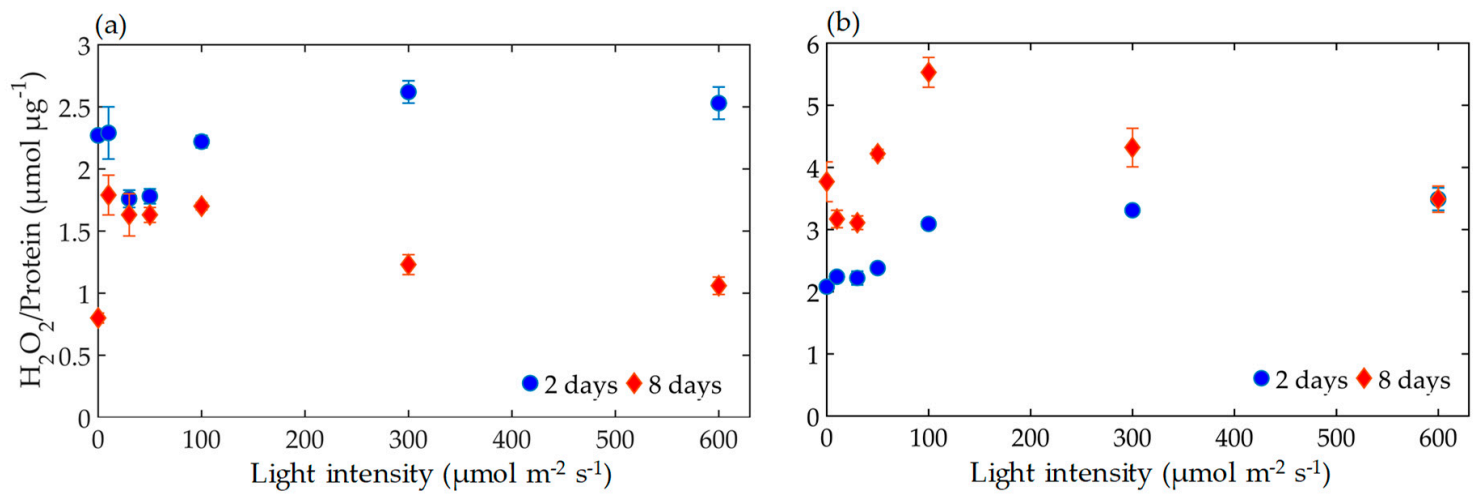

Figure 4. Changes in $\mathrm{H}_{2} \mathrm{O}_{2}$ /protein with respect to culture light intensity. (a) P. galeata; (b) M. aeruginosa, after two and eight days.

The relationship between Chl-a content and $\mathrm{H}_{2} \mathrm{O}_{2}$ is shown in Figure $5 \mathrm{a}, \mathrm{b}$. We found a clear negative correlation between Chl-a content and $\mathrm{H}_{2} \mathrm{O}_{2}$ for $P$. galeata (correlation coefficient, $\mathrm{r}=0.94$ ) and $M$. aeruginosa $(\mathrm{r}=0.71)$ after the two-day period only. The Chl-a content and $\mathrm{H}_{2} \mathrm{O}_{2}$ results were scattered beyond the two-day period. Both species P. galeata $\left(F_{6,28}=40.569\right.$ and $\left.p<0.0001\right)$ and M. aeruginosa $\left(F_{6,28}=16.026\right.$ and $\left.p<0.0001\right)$ showed statistically significant differences.
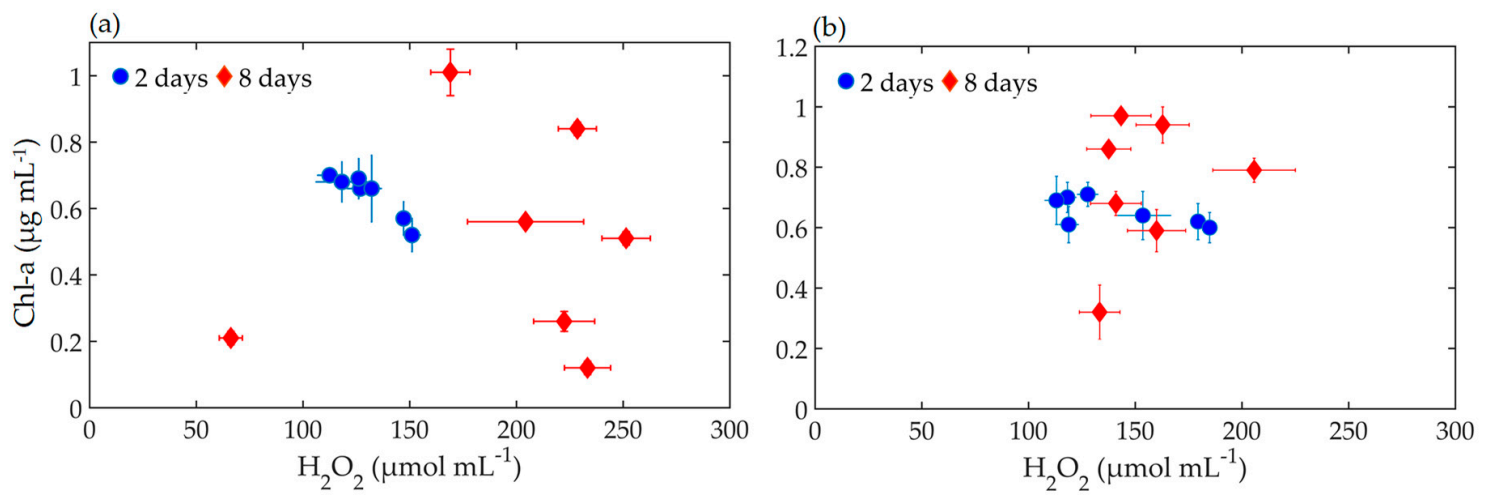

Figure 5. Chl-a content and $\mathrm{H}_{2} \mathrm{O}_{2}$. (a) P. galeata; (b) M. aeruginosa, after two and eight days.

Figure $6 \mathrm{a}, \mathrm{b}$ depicts the $\mathrm{H}_{2} \mathrm{O}_{2}$ per $\mathrm{OD}_{730}\left(\mathrm{H}_{2} \mathrm{O}_{2} / \mathrm{OD}_{730}\right)$ variation with respect to light intensity for both species after two and eight days. After two days, $\mathrm{P}$. galeata $\mathrm{H}_{2} \mathrm{O}_{2} / \mathrm{OD}_{730}$ remained the same across the light intensities. However, for $M$. aeruginosa, $\mathrm{H}_{2} \mathrm{O}_{2} / \mathrm{OD}_{730}$ decreased for 10 and $30 \mu \mathrm{mol}$ $\mathrm{m}^{-2} \mathrm{~s}^{-1}$, and then increased with further increasing light intensities. After eight days, P. galeata $\mathrm{H}_{2} \mathrm{O}_{2} / \mathrm{OD}_{730}$ increased more significantly than after two days of exposure, except for under $30 \mu \mathrm{mol}$ $\mathrm{m}^{-2} \mathrm{~s}^{-1}\left(F_{6,28}=69.894, p<0.0001\right)$. For $M$. aeruginosa, $\mathrm{H}_{2} \mathrm{O}_{2} / \mathrm{OD}_{730}$ decreased significantly from a light intensity of $30 \mu \mathrm{mol} \mathrm{m} \mathrm{m}^{-2} \mathrm{~s}^{-1}\left(F_{6,28}=13.964, p<0.0001\right)$. We identified a clearer positive correlation between $\mathrm{H}_{2} \mathrm{O}_{2} / \mathrm{OD}_{730}$ and light intensity for $P$. galeata after two days of exposure $(\mathrm{r}=0.74)$ and after eight-day exposure $(r=0.88)$, as well as for $M$. aeruginosa after two $(r=0.91)$ and eight $(r=0.54)$ days of exposure. 

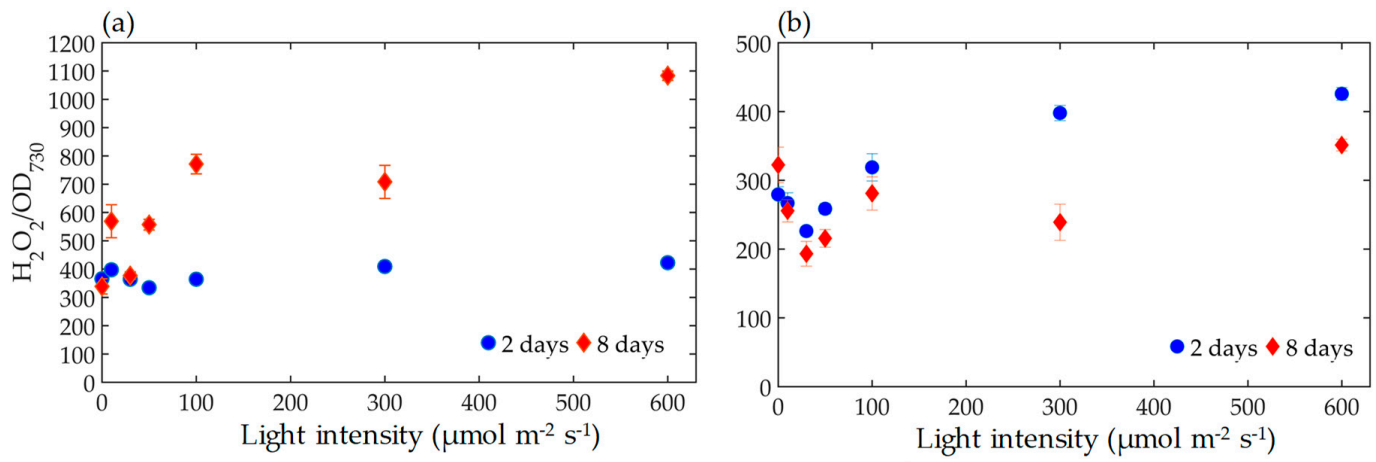

Figure 6. $\mathrm{H}_{2} \mathrm{O}_{2} / \mathrm{OD}_{730}$ with respect to culture light intensity. (a) P. galeata; (b) M. aeruginosa, under

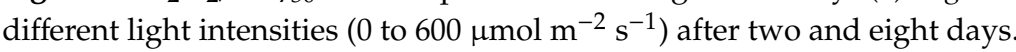

The CAT activity of two cyanobacteria species were found to be a function of $\mathrm{H}_{2} \mathrm{O}_{2}$ /protein, as shown in Figure 7a,b. P. galeata showed a statistically significant difference $\left(F_{6,28}=2.870, p=0.026\right)$, as did $M$. aeruginosa $\left(F_{6,28}=2.881, p=0.026\right)$. The CAT activity was highest for the two-day period for the highest $\mathrm{H}_{2} \mathrm{O}_{2}$ /protein values; after that, its value decreased with decreasing $\mathrm{H}_{2} \mathrm{O}_{2}$ /protein for P. galeata. In contrast, $\mathrm{H}_{2} \mathrm{O}_{2}$ /protein increased with time for $M$. aeruginosa, therefore, a higher CAT activity was generated.
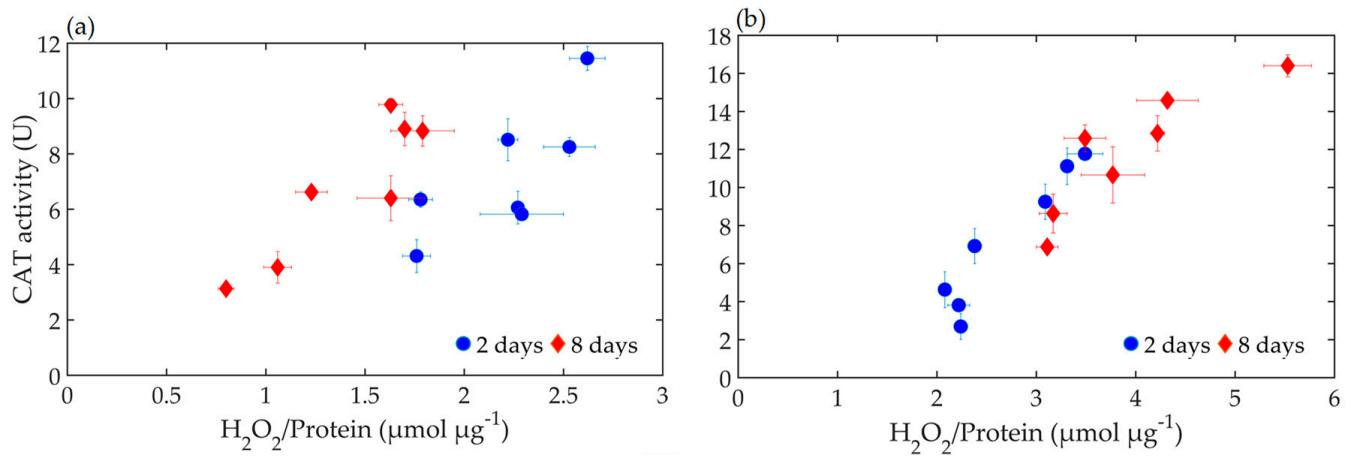

Figure 7. Catalase (CAT) activity with respect to $\mathrm{H}_{2} \mathrm{O}_{2}$ /protein. (a) P. galeata; (b) M. aeruginosa, under different light intensities ( 0 to $600 \mu \mathrm{mol}$ photons $\mathrm{m}^{-2} \mathrm{~s}^{-1}$ ) after two and eight days.

The POD activity of the two cyanobacteria species was also found to be a function of $\mathrm{H}_{2} \mathrm{O}_{2}$ /protein, as shown in Figure 8a,b. P. galeata showed a statistically significant difference $\left(F_{6,28}=16.452, p<0.0001\right)$, as did $M$. aeruginosa $\left(F_{6,28}=3.640, p=0.009\right)$. In P. galeata, POD activity after two days was higher than that in the eight-day experiment. In contrast, in M. aeruginosa, the POD activity increased with increasing $\mathrm{H}_{2} \mathrm{O}_{2}$ /protein during both experiments.
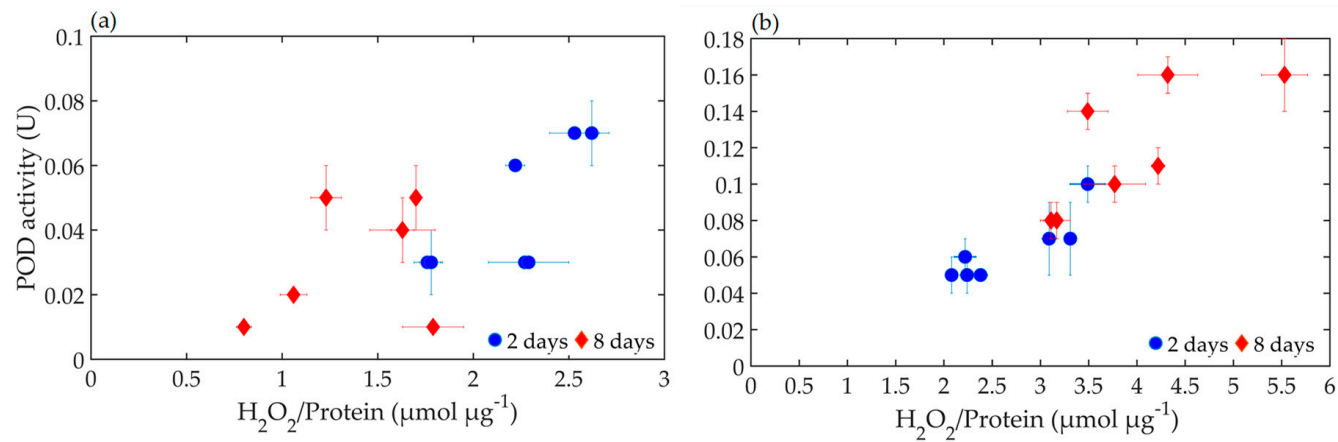

Figure 8. Peroxidase (POD) activity in relation to $\mathrm{H}_{2} \mathrm{O}_{2}$ /protein. (a) P. Galeata; (b) M. aeruginosa, under different light intensities ( 0 to $600 \mu \mathrm{mol} \mathrm{m} \mathrm{m}^{-2} \mathrm{~s}^{-1}$ ) after two and eight days. 
The trend was also observed in the color of the sample, which changed after both periods under different light intensities, as shown in Figure 9.

(a) P. galeata (strain NIES 512)

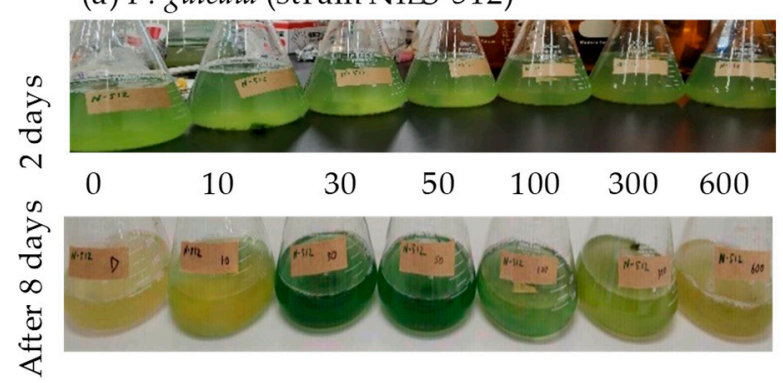

(b) M. aeruginosa (strain NIES 111)

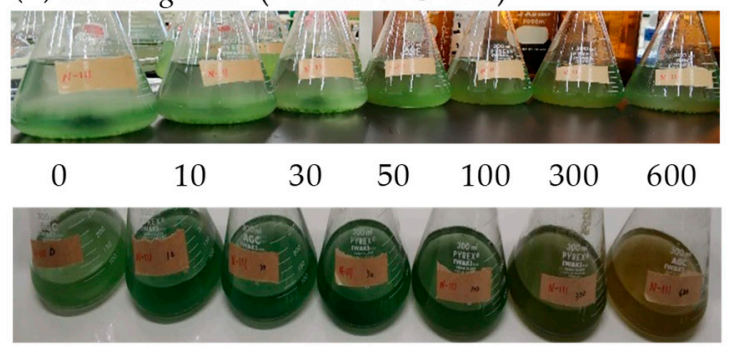

Figure 9. Photographs showing growth during the two- and eight-day periods. (a) P. galeata; (b) M. aeruginosa, under different light intensities $\left(0\right.$ to $\left.600 \mu \mathrm{mol} \mathrm{m}^{-2} \mathrm{~s}^{-1}\right)$.

The observed growth rates were fitted to the models proposed by Steele (Model I) [25], Platt and Jassby (Model II) [26], and Peeters and Eilers (Model III) [27]. The observed two-day growth rate of P. galeata fitted Model II, and the eight-day growth rate fitted Model I (Figure 10). The observed twoand eight-day data of M. aeruginosa fitted Model III, and the eight-day data fitted model III. P. galeata attained a maximum growth rate of 0.13 day $^{-1}$ within the first two days under a light intensity of $100 \mu \mathrm{mol} \mathrm{m}{ }^{-2} \mathrm{~s}^{-1}$, whereas M. aeruginosa attained a maximum growth rate of 0.15 day $^{-1}$ within the first two days under a light intensity of $30 \mu \mathrm{mol} \mathrm{m} \mathrm{m}^{-2} \mathrm{~s}^{-1}$ (Figure 11). The mean growth rates of P. galeata and $M$. aeruginosa were 0.08 day $^{-1}$ and 0.12 day $^{-1}$, respectively, achieved under a light intensity of $30 \mu \mathrm{mol} \mathrm{m} \mathrm{m}^{-2} \mathrm{~s}^{-1}$.

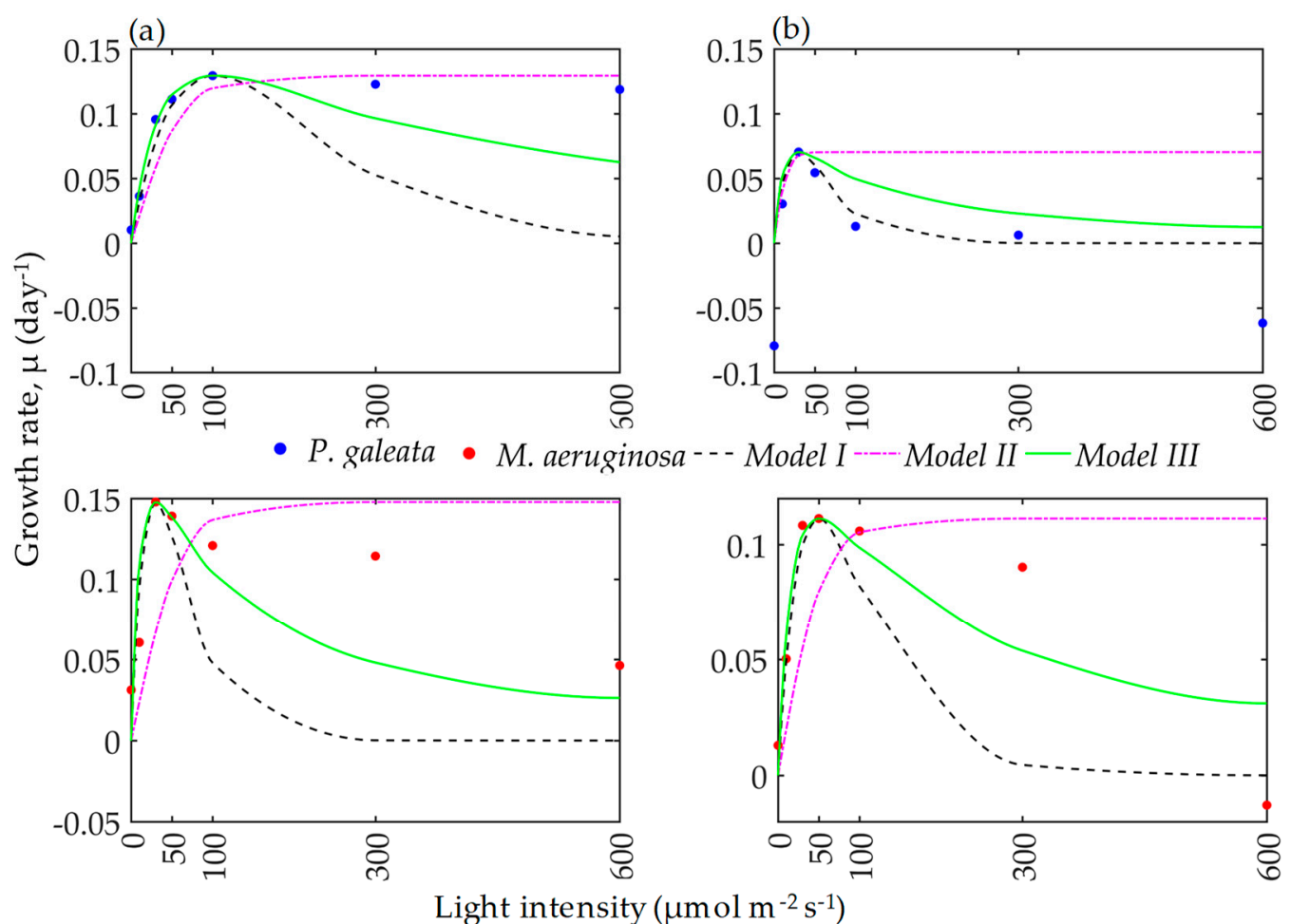

Figure 10. Growth rates of $P$. galeata and M. aeruginosa as a function of light intensity at different time intervals. (a) Two days; (b) eight days. The observed data were fitted with the models proposed by Steele (Model I) [25], Platt and Jassby (Model II) [26], and Peeters and Eilers (Model III) [27]. 


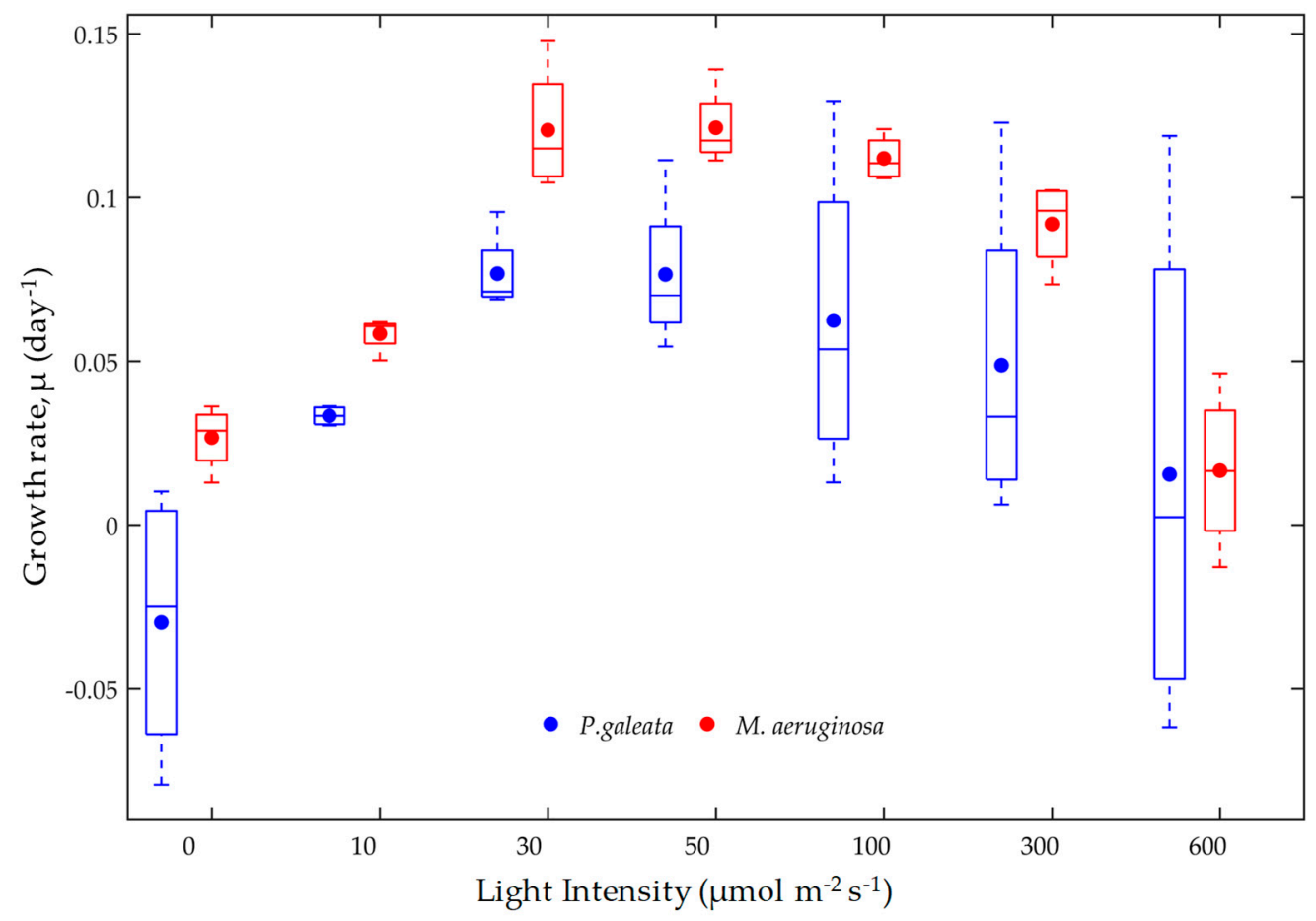

Figure 11. Comparison of growth rates of P. galeata and M. aeruginosa under different light intensities. The central lines indicate the median, and the bottom and top edges of each box indicate the 25th and 75th percentiles, respectively. The whiskers extend to the most extreme data points that were not considered outliers, and the circles indicate the mean value.

\section{Discussion}

Two cyanobacteria species, $P$. galeata and M. aeruginosa, exhibited different responses under different light intensities, and with respect to increasing light conditions, particularly when exceeding $50 \mu \mathrm{mol} \mathrm{m}{ }^{-2} \mathrm{~s}^{-1}$. P. galeata was negatively affected when the light intensity exceeded $100 \mu \mathrm{mol} \mathrm{m} \mathrm{m}^{-2} \mathrm{~s}^{-1}$, and $M$. aeruginosa was also negatively affected. However, under two days of exposure, neither species was influenced, even by the extreme light conditions ( 300 and $600 \mu \mathrm{mol} \mathrm{m}^{-2} \mathrm{~s}^{-1}$ ), suggesting that under a short exposure to high-light intensity, both species would survive. However, the extended exposure (eight days) increased the stress on both species. Therefore, both species have the capacity to tolerate light stress for shorter durations but lose this tolerance after extended exposure periods. Light intensities between 30 to $50 \mu \mathrm{mol} \mathrm{m}{ }^{-2} \mathrm{~s}^{-1}$ can be considered preferable light conditions for $P$. galeata growth; with a corresponding range of 10 to $100 \mu \mathrm{mol} \mathrm{m}^{-2} \mathrm{~s}^{-1}$ for M. aeruginosa (Figure 11). These findings show similar trends to previously published results, as the growth of Microcystis and Anabaena species increased under low light $\left(25 \mu \mathrm{mol} \mathrm{m}{ }^{-2} \mathrm{~s}^{-1}\right)$ but decreased under high light $\left(200 \mu \mathrm{mol} \mathrm{m}^{-2} \mathrm{~s}^{-1}\right)$ [22,24,34]. However, we confirmed that light intensities exceeding $200 \mu \mathrm{mol} \mathrm{m}^{-2} \mathrm{~s}^{-1}$ further intensified stress on both cyanobacteria species. As the only parameter that was varied in the present experiment was light, this suggests that cells become stressed mainly due to photosystem-produced $\mathrm{H}_{2} \mathrm{O}_{2}$, even at light intensities under $600 \mu \mathrm{mol} \mathrm{m} \mathrm{m}^{-2} \mathrm{~s}^{-1}$, as in most cyanobacteria species, photoinhibition occurred when the light intensity exceeded $1000 \mu \mathrm{mol} \mathrm{m}^{-2} \mathrm{~s}^{-1}$ [40-42].

The reduced protein content, which reflects increased stress or vice versa for M. aeruginosa and most cyanobacteria species [43], decreased more after the eight-day period than the two-day period, independent from the light intensity. This reveals that M. aeruginosa has a defense mechanism to prevent cell damage from light (Figure 1a,b). The observed decreases in protein content with increasing light intensity in M. aeruginosa are a result of decreased phycobiliprotein synthesis, which protects against the absorption of excess light energy and the increased degradation of protein by proteases [44-46]. The increased $\mathrm{OD}_{730}$ of $M$. aeruginosa, except at 0 and $600 \mu \mathrm{mol} \mathrm{m}^{-2} \mathrm{~s}^{-1}$ (two- and eight-day differences 
in $M$. aeruginosa $\mathrm{OD}_{730}$ under $600 \mu \mathrm{mol} \mathrm{m} \mathrm{m}^{-2} \mathrm{~s}^{-1}$ minimum as compared with P. galeata), evidences the survival and continuous cell proliferation of M. aeruginosa. P. galeata, which appeared to be relatively weak, strictly preferred 30 and $50 \mu \mathrm{mol} \mathrm{m}^{-2} \mathrm{~s}^{-1}$, and experienced high stress under lower or higher light intensities, considering the Chl-a content and $\mathrm{OD}_{730}$. However, the observed increases in protein content with increasing light stress suggest that there was a deviated stress response for P. galeata. The increased protein content can be associated with the upregulation of stress-related protein, as the oxidative stress was enforced due to the elevated $\mathrm{H}_{2} \mathrm{O}_{2}$ content with increasing light intensity [47]. However, further research focused on the upregulation of stress proteins is necessary to confirm this phenomenon.

The oxidative stress response mechanism, in cyanobacteria, helps to protect from extreme environmental conditions and can trigger antioxidant defense system responses [48]. The balance between the oxidative stress and antioxidative enzymes is disturbed by abiotic stress factors, and cells are subjected to oxidative stress in these conditions [49,50]. In this study, the $\mathrm{H}_{2} \mathrm{O}_{2}$ concentrations of both species were enhanced under low light $\left(0\right.$ and $\left.10 \mu \mathrm{mol} \mathrm{m}^{-2} \mathrm{~s}^{-1}\right)$ and high light (100 to $600 \mu \mathrm{mol} \mathrm{m}^{-2} \mathrm{~s}^{-1}$ ) intensities. After two days, the CAT and POD activities of P. galeata showed scattered trends with respect to oxidative stress (Figure 7), whereas for M. aeruginosa, they showed increasing trends (Figure 8). However, when testing the regression relationships between $\mathrm{H}_{2} \mathrm{O}_{2}$ /protein and antioxidant enzymes, CAT activity was found to have a strong relationship as compared with the POD of both species (CAT: M. aeruginosa $\mathrm{r}=0.89$ and P. galeata $\mathrm{r}=0.90$; POD: M. aeruginosa $\mathrm{r}=0.75$ and P. galeata $\mathrm{r}=0.45$ ). This confirms that the CAT activity of both cyanobacteria species played a more prominent antioxidant activity role than POD. Under higher stress, the antioxidant balance was also lost.

These findings show that high levels of light exposure can be adopted as a non-chemical method to control P. galeata and M. aeruginosa. This approach differs from methods such as the artificial mixing of water in lakes and reservoirs, which are based on the hypothesis that low-light exposure suppresses cyanobacteria growth [21]. However, we suggest that, in the case of controlling of $P$. galeata and M. aeruginosa, both low- and high-light exposure can be used effectively. Practical methods should be further studied to determine the field implications of high-light exposure for controlling these species. Particular focus should be given to methods that would keep the water column illuminated, thereby exceeding the light levels tolerable for P. galeata and M. aeruginosa. The growth performance of these two cyanobacteria species was fitted with one or more mathematical models tested (Figure 10), which confirmed the fit of the present data for the evaluation of growth responses of P. galeata and $M$. aeruginosa under low- and high-light conditions.

\section{Conclusions}

The availability of 30 to $50 \mu \mathrm{mol} \mathrm{m} \mathrm{m}^{-2} \mathrm{~s}^{-1}$ light was found to be a favorable illumination range for P. galeata, with the corresponding range for M. aeruginosa being 10 to $100 \mu \mathrm{mol} \mathrm{m}{ }^{-2} \mathrm{~s}^{-1}$. Beyond the optimal light intensities, the growth of the two cyanobacteria species was reduced. M. aeruginosa demonstrated higher tolerance to higher light intensities than P. galeata. High-light intensities, at which growth was lowest, could be used to develop control mechanisms, or to improve the present methods based on low-light exposure. This could help to effectively control cyanobacteria in water bodies. The fitting of the present results with the cyanobacteria growth models confirms that the growth responses of $P$. galeata and $M$. aeruginosa to different light conditions can be modeled to predict and control their occurrence.

Author Contributions: For conceptualization and methodology, G.M. and T.A.; software, validation, formal analysis, and writing-original draft preparation, G.M.; writing-review and editing, G.M., T.A., S.M.D.H.J., M.B.B., and M.H.R.; supervision, T.A.; data curation, G.M, M.B., H.D.L.A., and H.Y.; funding Acquisition, T.A. and S.J. All authors have read and agreed to the published version of the manuscript.

Funding: This research was funded by the Japan Society for the Promotion of Science (JSPS), JSPS KAKENHI grant numbers 19H02245 and 18K13833. 
Acknowledgments: We would like to give special thanks to Saitama University for providing laboratory and also give thanks to Kyoko Endo for administrative role during purchasing chemicals, materials and tools for this research study.

Conflicts of Interest: The authors declare no conflict of interest.

\section{References}

1. Trolle, D.; Nielsen, A.; Rolighed, J.; Thodsen, H.; Andersen, H.; Karlsson, I.; Refsgaard, J.C.; Olesen, J.; Bolding, K.; Kronvang, B.; et al. Projecting the future ecological state of lakes in Denmark in a 6 degree warming scenario. Clim. Res. 2015, 64, 55-72. [CrossRef]

2. Wang, B.; Wang, X.; Hu, Y.; Chang, M.; Bi, Y.; Hu, Z. The combined effects of UV-C radiation and $\mathrm{H} 2 \mathrm{O} 2$ on Microcystis aeruginosa, a bloom-forming cyanobacterium. Chemosphere 2015, 141, 34-43. [CrossRef]

3. Demoulin, C.F.; Lara, Y.J.; Cornet, L.; François, C.; Baurain, D.; Wilmotte, A.; Javaux, E.J. Cyanobacteria evolution: Insight from the fossil record. Free. Radic. Boil. Med. 2019, 140, 206-223. [CrossRef]

4. Yan, D.; Xu, H.; Yang, M.; Lan, J.; Hou, W.; Wang, F.; Zhang, J.; Zhou, K.; An, Z.; Goldsmith, Y. Responses of cyanobacteria to climate and human activities at Lake Chenghai over the past 100 years. Ecol. Indic. 2019, 104, 755-763. [CrossRef]

5. Śliwińska-Wilczewska, S.; Cieszyńska, A.; Konik, M.; Maculewicz, J.; Latała, A. Environmental drivers of bloom-forming cyanobacteria in the Baltic Sea: Effects of salinity, temperature, and irradiance. Estuarine, Coast. Shelf Sci. 2019, 219, 139-150. [CrossRef]

6. Mazur-Marzec, H.; Sutryk, K.; Kobos, J.; Hebel, A.; Hohlfeld, N.; Błaszczyk, A.; Toruńska, A.; Kaczkowska, M.J.; Łysiak-Pastuszak, E.; Kraśniewski, W. Occurrence of cyanobacteria and cyanotoxin in the Southern Baltic Proper. Filamentous cyanobacteria versus single-celled picocyanobacteria. Hydrobiologia 2013, 701, 235-252. [CrossRef]

7. Codd, G.A.; Morrison, L.F.; Metcalf, J.S. Cyanobacterial toxins: Risk management for health protection. Toxicol. Appl. Pharmacol. 2005, 203, 264-272. [CrossRef]

8. Pearson, L.; Mihali, T.; Moffitt, M.; Kellmann, R.; Neilan, B. On the Chemistry, Toxicology and Genetics of the Cyanobacterial Toxins, Microcystin, Nodularin, Saxitoxin and Cylindrospermopsin. Mar. Drugs 2010, 8 , 1650-1680. [CrossRef]

9. Paerl, H.W.; Huisman, J. Climate change: A catalyst for global expansion of harmful cyanobacterial blooms. Environ. Microbiol. Rep. 2009, 1, 27-37. [CrossRef]

10. O'Neil, J.; Davis, T.; Burford, M.; Gobler, C. The rise of harmful cyanobacteria blooms: The potential roles of eutrophication and climate change. Harmful Algae 2012, 14, 313-334. [CrossRef]

11. Huisman, J.; Codd, G.A.; Paerl, H.W.; Ibelings, B.W.; Verspagen, J.M.H.; Visser, P.M. Cyanobacterial blooms. Nat. Rev. Genet. 2018, 16, 471-483. [CrossRef]

12. Barros, M.U.; Wilson, A.E.; Leitão, J.I.; Pereira, S.P.; Buley, R.P.; Fernandez-Figueroa, E.G.; Capelo-Neto, J. Environmental factors associated with toxic cyanobacterial blooms across 20 drinking water reservoirs in a semi-arid region of Brazil. Harmful Algae 2019, 86, 128-137. [CrossRef] [PubMed]

13. Berg, M.; Sutula, M. Factors affecting the growth of cyanobacteria with special emphasis on the Sacramento-San Joaquin Delta. South. Calif. Coast. Water Res. Proj. Tech. Rep. 2015, 869, 7-28.

14. Khatoon, H.; Leong, L.K.; Rahman, N.A.; Mian, S.; Begum, H.; Banerjee, S.; Endut, A. Effects of different light source and media on growth and production of phycobiliprotein from freshwater cyanobacteria. Bioresour. Technol. 2018, 249, 652-658. [CrossRef] [PubMed]

15. Abeynayaka, H.D.L.; Asaeda, T.; Rashid, M.H. Effects of elevated pressure on Pseudanabaena galeata Böcher in varying light and dark environments. Environ. Sci. Pollut. Res. 2018, 25, 21224-21232. [CrossRef] [PubMed]

16. Kakimoto, M.; Ishikawa, T.; Miyagi, A.; Saito, K.; Miyazaki, M.; Asaeda, T.; Yamaguchi, M.; Uchimiya, H.; Kawai-Yamada, M. Culture temperature affects gene expression and metabolic pathways in the 2-methylisoborneol-producing cyanobacterium Pseudanabaena galeata. J. Plant Physiol. 2014, 171, 292-300. [CrossRef] [PubMed]

17. Dang, T.C.; Fujii, M.; Rose, A.L.; Bligh, M.; Waite, T.D. Characteristics of the freshwater cyanobacterium Microcystis aeruginosa grown in iron-limited continuous culture. Appl. Environ. Microbiol. 2012, 78, 1574-1583. [CrossRef] 
18. Princiotta, S.D.; Hendricks, S.P.; White, D.S. Production of Cyanotoxins by Microcystis aeruginosa Mediates Interactions with the Mixotrophic Flagellate Cryptomonas. Toxins 2019, 11, 223. [CrossRef]

19. Glibert, P.M. Harmful algae at the complex nexus of eutrophication and climate change. Harmful Algae 2019, 101583. [CrossRef]

20. Lürling, M.; Van Oosterhout, F.; Faassen, E. Eutrophication and Warming Boost Cyanobacterial Biomass and Microcystins. Toxins 2017, 9, 64. [CrossRef]

21. Visser, P.M.; Ibelings, B.W.; Bormans, M.; Huisman, J. Artificial mixing to control cyanobacterial blooms: A review. Aquat. Ecol. 2016, 50, 423-441. [CrossRef]

22. Islam, M.A.; Beardall, J. Growth and Photosynthetic Characteristics of Toxic and Non-Toxic Strains of the Cyanobacteria Microcystis aeruginosa and Anabaena circinalis in Relation to Light. Microorganisms 2017, 5, 45. [CrossRef] [PubMed]

23. Muramatsu, M.; Hihara, Y. Acclimation to high-light conditions in cyanobacteria: From gene expression to physiological responses. J. Plant Res. 2012, 125, 11-39. [CrossRef] [PubMed]

24. Venugopal, V.; Prasanna, R.; Sood, A.; Jaiswal, P.; Kaushik, B.D. Stimulation of pigment accumulation in Anabaena azollae strains: Effect of light intensity and sugars. Folia Microbiol. 2006, 51, 50-56. [CrossRef] [PubMed]

25. Steele, J.H. Notes on some theoketical pkoblems in pkoduction ecology. Prim. Product. Aquat. Environ. 1965, 18, 383.

26. Platt, T.; Jassby, A.D. The relationship between photosynthesis and light for natural assemblages of coastal marine phyoplankton. J. Phycol. 1976, 12, 421-430.

27. Peeters, J.C.H.; Eilers, P. The relationship between light intensity and photosynthesis-A simple mathematical model. Aquat. Ecol. 1978, 12, 134-136. [CrossRef]

28. Rippka, R.; Stanier, R.Y.; Deruelles, J.; Herdman, M.; Waterbury, J.B. Generic Assignments, Strain Histories and Properties of Pure Cultures of Cyanobacteria. Microbiol. 1979, 111, 1-61. [CrossRef]

29. Guan, Y.; Deng, M.; Yu, X.; Zhang, W. Two-stage photo-biological production of hydrogen by marine green alga Platymonas subcordiformis. Biochem. Eng. J. 2004, 19, 69-73. [CrossRef]

30. Bradford, M.M. A rapid and sensitive method for the quantitation of microgram quantities of protein utilizing the principle of protein-dye binding. Anal. Biochem. 1976, 72, 248-254. [CrossRef]

31. Axler, R.P.; Owen, C.J. Measuring chlorophyll and phaeophytin: Whom should you believe? Lake Reserv. Manag. 1994, 8, 143-151. [CrossRef]

32. Association, A.P.H.; Association, A.W.W.; Federation, W.P.C.; Federation, W.E. Standard Methods for the Examination of Water and Wastewater; American Public Health Association: Washington, DC, USA, 1915; ISBN 8755-3546.

33. Holm, G. Chlorophyll Mutations in Barley. Acta Agric. Scand. 1954, 4, 457-471. [CrossRef]

34. Romo, S. Growth parameters of Pseudanabaena galeata Böcher in culture under different light and temperature conditions. Algol. Stud. für Hydrobiol. Suppl. 1994, 75, 239-248.

35. Jana, S.; Choudhuri, M.A. Effects of plant growth regulators on Hill activity of submerged aquatic plants during induced senescence. Aquat. Bot. 1984, 18, 371-376. [CrossRef]

36. Aebi, H. Catalase in vitro. In Tumor Immunology and Immunotherapy Endash; Cellular Methods Part B; Elsevier: Amsterdam, The Netherlands, 1984; pp. 121-126.

37. Macadam, J.W.; Nelson, C.J.; Sharp, R.E. Peroxidase Activity in the Leaf Elongation Zone of Tall Fescue: I. Spatial Distribution of Ionically Bound Peroxidase Activity in Genotypes Differing in Length of the Elongation Zone. Plant Physiol. 1992, 99, 872-878. [CrossRef]

38. Foy, R.H.; Gibson, C.E.; Smith, R. V The influence of daylength, light intensity and temperature on the growth rates of planktonic blue-green algae. Br. Phycol. J. 1976, 11, 151-163. [CrossRef]

39. Sabour, B.; Sbiyyaa, B.; Loudiki, M.; Oudra, B.; Belkoura, M.; Vasconcelos, V. Effect of light and temperature on the population dynamics of two toxic bloom forming Cyanobacteria-Microcystis ichthyoblabe and Anabaena aphanizomenoides. Chem. Ecol. 2009, 25, 277-284. [CrossRef]

40. Whitelam, G.C.; Cold, G.A. Photoinhibition of photosynthesis in the cyanobacterium Microcystis aeruginosa. Planta 1983, 157, 561-566. [CrossRef]

41. Machová, K.; Elster, J.; Adamec, L. Xanthophyceaen assemblages during winter-spring flood: Autecology and ecophysiology of Tribonema fonticolum and T. monochloron. Hydrobiologia 2008, 600, 155-168. [CrossRef] 
42. Harel, Y.; Ohad, I.; Kaplan, A. Activation of Photosynthesis and Resistance to Photoinhibition in Cyanobacteria within Biological Desert Crust1[w]. Plant Physiol. 2004, 136, 3070-3079. [CrossRef]

43. Kaebernick, M.; Neilan, B.A.; Börner, T.; Dittmann, E. Light and the Transcriptional Response of the Microcystin Biosynthesis Gene Cluster. Appl. Environ. Microbiol. 2000, 66, 3387-3392. [CrossRef] [PubMed]

44. De Oliveira, C.A.; Oliveira, W.C.; Ribeiro, S.M.R.; Stringheta, P.C.; Nascimento, A.G. Effect of light intensity on the production of pigments in Nostoc SPP. Eur. J. Biol. Med. Sci. Res. 2014, 2, 23-36.

45. Pojidaeva, E.; Zinchenko, V.; Shestakov, S.V.; Sokolenko, A. Involvement of the SppA1 Peptidase in Acclimation to Saturating Light Intensities in Synechocystis sp. Strain PCC 6803. J. Bacteriol. 2004, 186, 3991-3999. [CrossRef] [PubMed]

46. Rosales-Loaiza, N.; Guevara, M.; Lodeiros, C.; Morales, E. Crecimiento y producción de metabolitos de la cianobacteria marina Synechococcus sp.(Chroococcales) en función de la irradiancia. Rev. Biol. Trop. 2008, 56, 421-429. [CrossRef]

47. Babele, P.K.; Kumar, J.; Chaturvedi, V. Proteomic De-Regulation in Cyanobacteria in Response to Abiotic Stresses. Front. Microbiol. 2019, 10, 1315. [CrossRef]

48. Liu, M.; Shi, X.; Chen, C.; Yu, L.; Sun, C. Responses of Microcystis Colonies of Different Sizes to Hydrogen Peroxide Stress. Toxins 2017, 9, 306. [CrossRef]

49. De Silva, H.C.C.; Asaeda, T. Effects of heat stress on growth, photosynthetic pigments, oxidative damage and competitive capacity of three submerged macrophytes. J. Plant Interactions 2017, 12, 228-236. [CrossRef]

50. Rastogi, R.P.; Singh, S.P.; Häder, D.-P.; Sinha, R.P. Detection of reactive oxygen species (ROS) by the oxidant-sensing probe $2^{\prime}, 7^{\prime}$-dichlorodihydrofluorescein diacetate in the cyanobacterium Anabaena variabilis PCC 7937. Biochem. Biophys. Res. Commun. 2010, 397, 603-607. [CrossRef]

(C) 2020 by the authors. Licensee MDPI, Basel, Switzerland. This article is an open access article distributed under the terms and conditions of the Creative Commons Attribution (CC BY) license (http://creativecommons.org/licenses/by/4.0/). 